\title{
Exploring the oxygen challenge test as a microcirculation evaluation model
}

\section{Explorando o teste de provocação com oxigénio como modelo de avaliação da microcirculação}

\author{
Henrique Silva ${ }^{1,2^{*}}$, Hugo Ferreira ${ }^{3}$, Julia Bujan ${ }^{4}$ and L Monteiro Rodrigues ${ }^{1,2}$ \\ ${ }^{1}$ CBIOS - Universidade Lusófona's Research Center for Biosciences and Health Technologies (UDE), Campo Grande 376, \\ 1749-024, Lisboa, Portugal \\ ${ }^{2}$ Pharmacol. Sc Depart - Universidade de Lisboa, School of Pharmacy, Lisboa, Portugal \\ ${ }^{3}$ Instituto de Biofísica e Engenharia Biomédica, Faculdade de Ciências da Universidade de Lisboa, Lisboa, Portugal \\ ${ }^{4}$ Faculty of Medicine, Alcalá de Henares, Madrid, Spain \\ Email: hnnsilva@hotmail.com
}

*This project is supported by the grant PADDIC 2012-2013, from ALIES-COFAC and part of the PhD Program in Health Sciences from U Alcalá and U Lusófona.

*Este projeto é apoiado pela concessão PADDIC 2012-2013, a partir de ALIES-COFAC e faz parte do Programa de

Doutoramento em Ciências da Saúde pela U Alcalá e U Lusófona

\begin{abstract}
Cutaneous microcirculation has emerged in recent years as a practical accessible subject for the study of peripheral circulation. Non-invasive techniques such as Laser Doppler Flowmetry (LDF), skin Evaporimetry and Transcutaneous Gasimetry in association with provocation tests, render cutaneous circulation a very attractive research model. This study was applied to a group of healthy young female volunteers, $(n=8,(21,6 \pm 2,6)$ years old) breathing a $100 \%$ oxygen atmosphere for 10 minutes. This test allowed us to evaluate the circulatory response in the lower limb microcirculation. Measurement techniques included local blood flow by LDF, Transcutaneous (tc) $\mathrm{pO}_{2}$ partial pressure and Transepidermal Water Loss (TEWL) by Evaporimetry. Data analysis revels that tc- $p \mathrm{O}_{2}$ and LDF changed significantly during the test. A reciprocal evolution profile was registered in LDF and TEWL, which seems to support previous data that changes in local blood flow may influence the epidermal "barrier" function. This model seems suitable to characterize the lower limb microcirculation.
\end{abstract}

Keywords: LDF, tc- $p \mathrm{O}_{2}$, oxygen breathing, hyperoxia, TEWL

\section{Resumo}

A microcirculação cutânea surgiu, nos últimos anos, como uma alternativa pratica e acessível para o estudo da circulação periférica. Técnicas não-invasivas, como a Fluxometria por Laser Doppler (FLD), a Evaporimetria e a Gasimetria transcutânea em associação a testes de provocação têm transformado a circulação cutânea num atraente modelo de investigação. Este estudo foi aplicado a um grupo de voluntárias jovens saudáveis $(n=8,(21,6$ $\pm 2,6$ ) anos) respirando uma atmosfera de $100 \%$ oxigénio durante 10 minutos. Este teste permitiu-nos avaliar a resposta circulatória na microcirculação do membro inferior. As técnicas de medição incluíram o fluxo sanguíneo local por FLD, a $p \mathrm{O}_{2}$ transcutânea (tc) e a Perda Transepidérmica de Água (PTEA) por evaporimetria. A análise de dados revela que tc- $p \mathrm{O}_{2}$ e FLD se alteraram significativamente durante o teste. Um perfil de evolução recíproca foi registrado para FLD e PTEA, que parece apoiar dados anteriores de que as alterações no fluxo sanguíneo local podem influenciar a função de "barreira" epidérmica. Este modelo parece adequado para caracterizar a microcirculação do membro inferior in vivo.

Palavras-chave: $\mathrm{FLD}$, tc- $p \mathrm{O}_{2}$, respiração de oxigénio, hiperóxia, PTEA 


\section{Introduction}

Cutaneous microcirculation has been used as a very practical accessible subject for the study of the peripheral circulation ${ }^{[1,2]}$ including vascular dysfunction mechanisms. ${ }^{[3-5]}$ It has been used as a research model in various diseases such as type II diabetes ${ }^{[6]}$ peripheral vascular disease ${ }^{[1]}$ and hypertension. ${ }^{[7]}$ Clinically, microcirculatory variables are also used as prognostic tools to assess severe limb ischemia, ${ }^{[8]}$ wound outcome [9] and also to eventually determine the amputation level. ${ }^{[10]}$ Laser Doppler Flowmetry (LDF), Transcutaneous Gasimetry and Evaporimetry are extensively used technologies that enable sensitive, continuous, non-invasive and real-time assessment of circulation related variables. ${ }^{[1-14]}$ Frequently, these techniques are coupled with provocation tests to stimulate vascular reactivity and therefore to investigate the physiological response evoked under control. ${ }^{[15]}$ The administration of normobaric oxygen, also known as the "oxygen challenge test", has been used to increase the sensitivity and specificity of tc- $p \mathrm{O}_{2}$ measurements. ${ }^{[16-19]}$ These studies suggest that the responsiveness to oxygen inhalation reflects vascular reactivity especially in ischemic tissues. [16-19] The systemic vasoconstrictory effects of oxygen inhalation, both normobaric and hyperbaric have been described for decades, and oxygen-induced decrease of regional blood flow has been clearly demonstrated in several vascular beds, including the brain, ${ }^{[20]}$ the heart, ${ }^{[21]}$ the retina ${ }^{[22]}$ and the limbs..$^{[23]}$

In the present study we have explored the application of a $100 \%$ normobaric oxygen breathing model to evaluate the in vivo microcirculation response in the lower limb to characterize the individual's peripheral vascular status.

\section{Materials and Methods}

A group of nine young female volunteers $((21,6 \pm 2,6)$ years old) was selected after informed consent. Volunteers were non-smokers and were not taking any kind of medication other than contraceptives. Restrictions included caffeine consumption and cosmetic products application in the lower limbs 24 hours before the test. All procedures complied with the ethical standards for human research outlined in the Declaration of Helsinki and subsequent amendments. ${ }^{[24]}$ Studied variables, obtained in distal locations of a randomly chosen lower

\section{Introdução}

A microcirculação cutânea tem sido usada como um sujeito especialmente prático e acessível para o estudo da circulação periférica ${ }^{[1,2]}$ incluindo os mecanismos de disfunção vascular. ${ }^{[3-5]}$ Tem sido ainda utilizada como um modelo de investigação em vários estados patológicos como a diabetes do tipo $\mathrm{II}^{[6]}$ a doença vascular periférica ${ }^{[1]}$ e a hipertensão ${ }^{[7]}$. No contexto clínico as variáveis microcirculatórias são utilizadas como ferramentas de prognóstico para avaliar a isquémia grave dos membros ${ }^{[8]}$, a evolução da ferida cutânea ${ }^{[9]} \mathrm{e}$, até para determinar o nível de amputação. ${ }^{[10]}$ A Fluxometria por Laser Doppler (FLD), a Gasimetria Transcutânea e a Evaporimetria são tecnologias amplamente utilizadas que permitem uma avaliação sensível, contínua, nãoinvasiva e em tempo real de variáveis relacionadas com a circulação. ${ }^{[11-14]}$ Estas técnicas são normalmente associadas a testes de provocação que podem estimular a reatividade vascular e, portanto, investigar a resposta fisiológica evocada sob controlo. ${ }^{[15]} \mathrm{A}$ administração de oxigénio normobárico, também conhecida como "teste de provocação com oxigénio", tem sido usada há vários anos como um meio para aumentar a sensibilidade e especificidade das medições da tc- $p \mathrm{O}_{2} \cdot{ }^{[16-19]}$ Estes estudos sugerem que a capacidade de resposta à inalação de oxigénio reflete a reatividade vascular, especialmente em zonas isquémicas. ${ }^{[16-19]}$ Os efeitos vasoconstritores sistémicos da inalação de oxigénio, tanto normobárico como hiperbárico têm sido descritos desde há décadas, e a diminuição do fluxo sanguíneo regional induzida pelo oxigénio tem sido claramente demonstrada em diversos leitos vasculares, incluindo no cérebro, ${ }^{[20]}$ coração, ${ }^{[21]}$ retina ${ }^{[22]}$ e membros. ${ }^{[23]}$

No presente estudo explorámos a aplicação de um modelo de respiração normobárica de oxigénio a 100 \% para avaliar a resposta da microcirculação in vivo da resposta da microcirculação no membro inferior para caracterizar o estado vascular periférico do indivíduo.

\section{Materiais e Métodos}

Um grupo de nove jovens voluntárias do sexo feminino $((21,6 \pm 2,6)$ anos $)$ foi selecionado após consentimento informado. As voluntárias eram não-fumadoras, não estavam a tomar qualquer tipo de medicação para além de anticoncecionais. Restrições incluíram o consumo de cafeína e a aplicação de produtos cosméticos nos membros inferiores 24 horas antes do teste. Todos os procedimentos cumpriram com as normas éticas para pesquisa com seres humanos descritos na Declaração de Helsinki e emendas subsequentes. ${ }^{[24]}$ As variáveis 
limb, involved microcirculatory blood flow $(\mathrm{mfs})$ in the inferior side of the second toe, by LDF (PeriFlux PF5000, PF5010 System, Perimed, Sweden) expressed in arbitrary units (AU); tcpO $\mathrm{O}_{2}$ on the root of the second toe, by transcutaneous gasimetry (Periflux PF5000, PF5040 tcpO $/ 2 \mathrm{CO}_{2}$ System, Perimed, Sweden) expressed in $\mathrm{mmHg}$; and TEWL on the superior side of the foot, on the projection of the root of the third and fourth toes, by evaporimetry (Tewameter TM300, CK electronics, Germany) expressed in $\mathrm{g} \mathrm{h}^{-1} \mathrm{~m}^{-2}$. After acclimatization, the volunteers breathed a $100 \%$ oxygen atmosphere for 30 minutes. This protocol included three phases, 10 minutes each - resting (phase I), provocation (phase II) and post-provocation (phase III), as illustrated in figure 1. For the phase II, a non-rebreathing system was employed, consisting of an AGA MedControl 45 Bar Oxygen Demand Valve facemask that prevented the entry of air coming from anywhere but the cylinder.

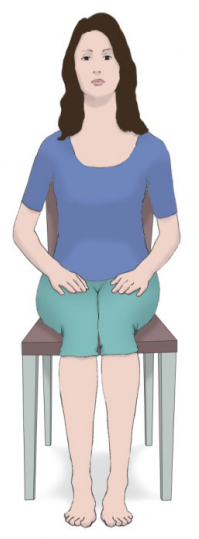

estudadas, obtidas em locais distais de um membro inferior escolhido aleatoriamente, envolveram o fluxo sanguíneo microcirculatório $(f s m)$ na face inferior do segundo dedo do pé, expresso em unidades arbitrárias (UA) por FLD (Periflux PF5000, Sistema PF5010, Perimed, Suécia); tcpO $\mathrm{O}_{2}$ sobre a raiz do segundo dedo, por gasimetria transcutânea (Periflux PF5000, Sistema PF5040 tcpO / tcpCO ${ }_{2}$, Perimed, Suécia) expressa em $\mathrm{mmHg}$, e PTEA sobre a raiz do terceiro e quarto dedos, por evaporimetria (Tewameter TM300, CK Electronics, Alemanha) expressa em $\mathrm{g} \mathrm{h}^{-1} \mathrm{~m}^{-2}$. Após aclimatização, as voluntárias realizaram um protocolo de respiração de oxigénio a $100 \%$, consistindo de três fases de 10 minutos cada - repouso (fase I), provocação (fase II) e pós-provocação (fase III) como ilustrado na figura 1. Para a fase II do protocolo foi usado um sistema de não-reinalação, consistindo numa máscara AGA MedControl 45 Bar Oxygen Demand Valve que impedia a entrada de ar não proveniente da garrafa.

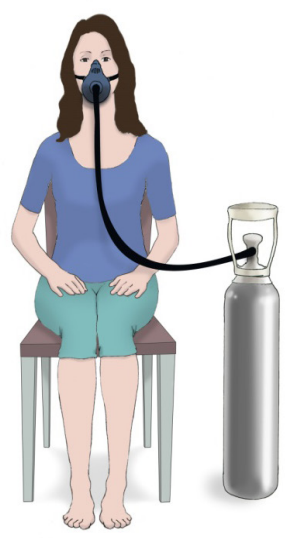

Figure 1 - The volunteer sits for 10 minutes breathing room atmosphere.

Then a mask is applied and the volunteer breathes a $100 \%$ oxygen saturated atmosphere for another 10 minutes. Finally the room atmosphere breathing is retained for a further 10 minutes.

Figura 1 - A voluntária está sentada durante 10 minutos a respirar a atmosfera da sala.

É então aplicada uma máscara e a voluntária respira uma atmosfera de $100 \%$ oxigénio por mais 10 minutos. Finalmente volta a respirar a atmosfera da sala por mais 10 minutos.

The statistical analysis involved the Wilcoxon matchedpairs signed-rank test with the adoption of a $95 \%$ confidence interval (IBM Corp. Released 2011. IBM SPSS Statistics for Windows, Version 20.0. Armonk, NY: IBM Corp). All remaining analyses were performed with MatLab software (MATLAB and Statistics Toolbox Release 2011, The MathWorks, Inc., Natick, Massachusetts, United States). In order to characterize the tissue capacity of oxygen extraction during the oxygen supplementation, several tc- $p \mathrm{O}_{2}$ curve-dependent parameters for phase II were determined, as used elsewhere ${ }^{[8,25]}$ - Area Under the Curve (AUC), tc- $p \mathrm{O}_{2}$ at 1-minute inhalation, tc- $p \mathrm{O}_{2}$ at 4-minute inhalation, tc- $p \mathrm{O}_{2}$ slope between minutes 1 and 4 of inhalation.
A análise estatística foi realizada através do Wilcoxon para amostras emparelhadas com a adoção de um intervalo de confiança de $95 \%$ (IBM SPSS Statistics for Windows, Versão 20.0. Armonk, NY: IBM Corp). Todas as restantes análises foram realizadas com o software MatLab (MATLAB and Statistics Toolbox Release 2011, The MathWorks, Inc., Natick, Massachusetts, United States). A fim de caracterizar a capacidade de extração de oxigénio pelos tecidos durante fase II, foram determinados vários parâmetros dependentes da curva de tc- $p \mathrm{O}_{2}$, conforme já descritos ${ }^{[8,24]}$ - Área Sob a Curva (ASC), tc- $p \mathrm{O}_{2}$ ao minuto 1 de inalação, tc- $p \mathrm{O}_{2}$ ao minuto 4 de inalação, declive da tc- $p \mathrm{O}_{2}$ entre os minutos 1 e 4 de inalação. 


\section{Results and Discussion}

The mean and standard deviation values of each variable from all volunteers, as well as the statistical significant differences are represented in table I and II. The perfusion reduction effect of the oxygen supplementation has been known for several years, and is thought to be attributed not to sympathetic stimulation ${ }^{[26,27]}$ but rather to the reactive oxygen species (ROS)-mediated inhibition of vasodilator prostanoid synthesis. ${ }^{[28]}$ As expected, during oxygen breathing in the provocation phase, tc- $\mathrm{pO}_{2}$ increased significantly, saturating hemoglobin and increasing its amount dissolved in plasma, thereby creating hyperoxia. In response to this increase, a vasoconstriction seemed to have occurred, which led to the statistically significant reduction of $m b f$. This change in blood flow may have created a redistribution of the local Starling forces, contributing to the increase, although not significant, of TEWL. The inverse behavior found for $m f b$ and $T E W L$ has been reported before, and suggests that, in some conditions, local perfusion might be a determinant of the epidermal "barrier" function $^{[15,29]}$ (figures 2 e 3 ).

\section{Resultados e Discussão}

Os valores de média e desvio-padrão de cada variável de todos os voluntários, bem como as diferenças estatisticamente significativas estão representados na tabela I e II. O efeito de redução da perfusão por suplementação de oxigénio é conhecido há vários anos, pensase ser atribuído não à estimulação simpática ${ }^{[25,26]}$, mas sim à inibição da síntese de prostanóides vasodilatadores mediada por espécies reativas de oxigénio (ERO).

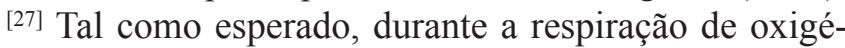
nio na fase de provocação, tc- $p \mathrm{O}_{2}$ aumentou significativamente, saturando a hemoglobina e aumentando a quantidade dissolvida no plasma, criando assim hiperóxia. Em resposta a este aumento parece ter ocorrido vasoconstrição, o que levou à redução estatisticamente significativa do $f_{s m}$. Esta alteração no fluxo sanguíneo pode ter criado uma redistribuição das forças de Starling locais, contribuindo para o aumento, embora não significativo, da PTEA. Este comportamento inverso encontrado para $f_{S m}$ e PTEA foi relatado anteriormente, e sugere que, em algumas condições, a perfusão local poderá ser um determinante da função de "barreira" epidérmica.

Table 1 - Average and standard deviation values of each studied variable for the last 5 minutes of each phase of the protocol.

Statistical comparison for the last 5 minutes of phase I. (N.S. - non significant; $p<0,05$ ).

Tabela 1 - Valores médios e desvios-padrão de cada variável para os últimos 5 minutos de cada fase do protocolo. Comparação estatística para os últimos 5 minutos da fase I (N.S. - não significativo; $p<0,05$ ).

\begin{tabular}{|c|c|c|c|}
\cline { 2 - 4 } \multicolumn{1}{c|}{} & Phase I / Fase I & Phase II / Fase II & Phase III / Fase III \\
\hline \multirow{2}{*}{ TEWL / $\left(\mathbf{g ~ h}^{-1} \mathbf{~ m}^{-2)}\right.$} & $6,5 \pm 2,7$ & $7,1 \pm 4,1$ & $5,7 \pm 2,3$ \\
\cline { 2 - 4 } & - & N.S. & N.S. \\
\hline$m f b /\left(\mathrm{g} \mathrm{h}^{-1} \mathrm{~m}^{-2}\right)$ & $\mathbf{A U}$ & $8,3 \pm 3,9$ & $12,7 \pm 9,0$ \\
\cline { 2 - 4 }$(f s m / \mathrm{UA})$ & - &, 008 & N.S. \\
\hline \multirow{2}{*}{$\mathbf{t c}-\boldsymbol{p} \mathbf{O}_{2} / \mathrm{mmHg}$} & $85,6 \pm 11,1$ & $201,6 \pm 78,7$ & $86,7 \pm 11,4$ \\
\cline { 2 - 4 } & - & 0,008 & N.S. \\
\hline
\end{tabular}

Table 2 - Phase II tc- $p \mathrm{O}_{2}$ characterization parameters (mean \pm standard deviation)

Tabela 2 - Parâmetros de caracterização da tc- $p \mathrm{O}_{2}$ da fase II (média \pm desvio-padrão)

\begin{tabular}{|c|c|}
\hline Parameters / Parâmetros & $\overline{\mathbf{x}} \pm \mathbf{s d}$ \\
\hline $\begin{array}{c}\text { Peak value / } \mathrm{mmHg} \\
\text { Valor máximo } / \mathrm{mmHg}\end{array}$ & $224,3 \pm 78,5$ \\
\hline $\begin{array}{c}\text { Time to peak / min } \\
\text { Tempo até ao valor máximo / min }\end{array}$ & $9,3 \pm 2,0$ \\
\hline $\begin{array}{c}A U C /(\mathrm{mmHg} \min ) \\
A S C /(\mathrm{mmHg} \cdot \mathrm{min})\end{array}$ & $9825,0 \pm 3474,9$ \\
\hline tc- $p \mathrm{O}_{2}(\mathrm{t}=1 \mathrm{~min}) / \mathrm{mmHg}$ & $84,9 \pm 9,2$ \\
\hline tc- $p \mathrm{O}_{2}(\mathrm{t}=4 \mathrm{~min}) / \mathrm{mmHg}$ & $159,2 \pm 49,8$ \\
\hline $\begin{array}{c}\text { tc- } p \mathrm{O}_{2} \text { slope }([1 ; 4] \mathrm{min}) /\left(\mathrm{mmHg} \mathrm{min}^{-1}\right) \\
\text { Declive de tc- } p \mathrm{O}_{2}([1 ; 4] \mathrm{min}) /\left(\mathrm{mmHg} \min ^{-1}\right)\end{array}$ & $24,7 \pm 13,5$ \\
\hline
\end{tabular}



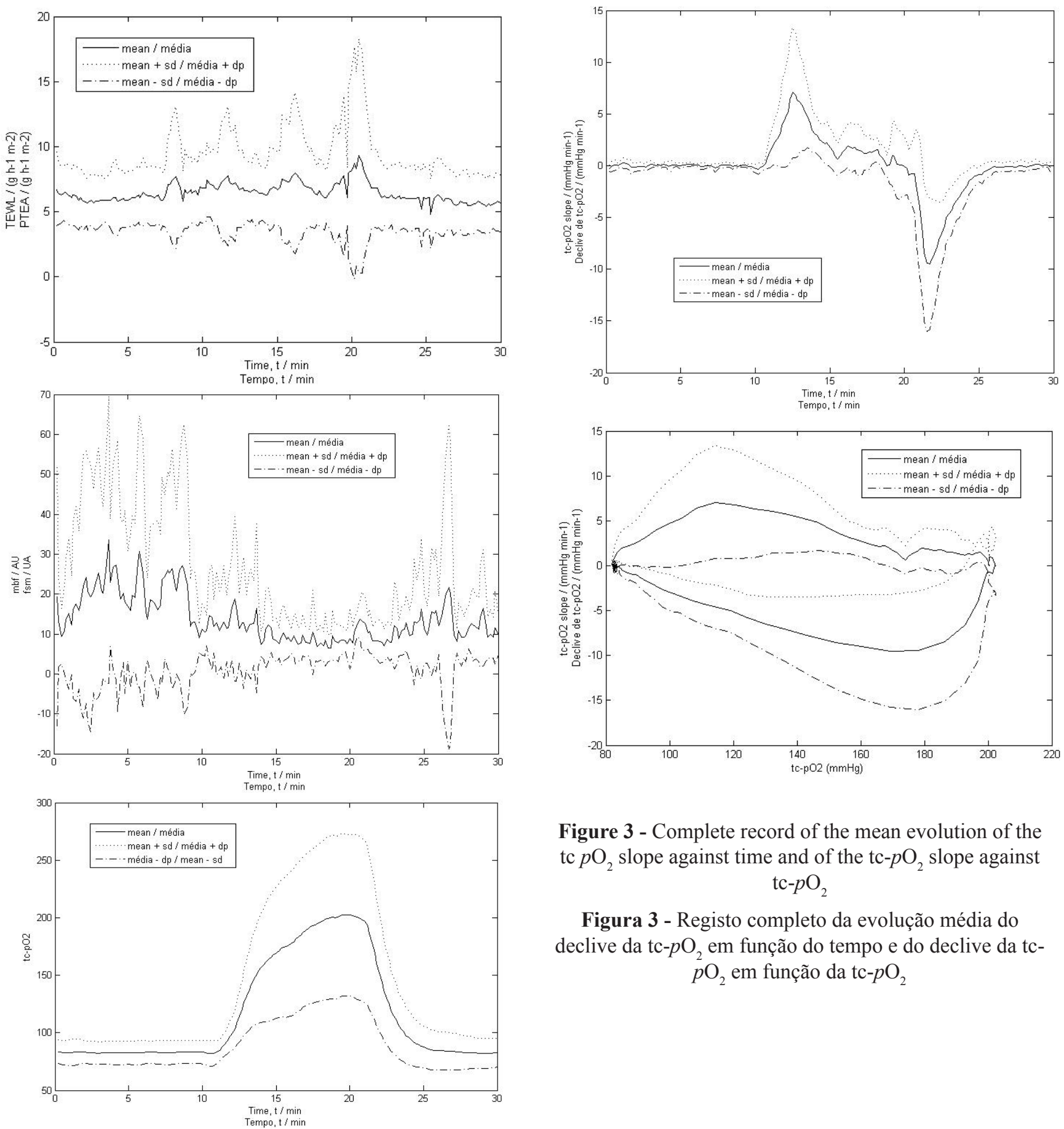

Figure 3 - Complete record of the mean evolution of the tc $p \mathrm{O}_{2}$ slope against time and of the tc- $p \mathrm{O}_{2}$ slope against tc $-p \mathrm{O}_{2}$

Figura 3 - Registo completo da evolução média do declive da tc- $p \mathrm{O}_{2}$ em função do tempo e do declive da tc$p \mathrm{O}_{2}$ em função da tc- $p \mathrm{O}_{2}$

Figure 2 - Complete record of the average evolution of the studied variables during the protocol

Figura 2 - Registo completo da evolução média das variáveis estudadas no decurso do protocolo 


\section{Conclusion}

The proposed model seems suitable to characterize the peripheral microcirculation in vivo.

\section{Acknowledgements}

The authors would like to express their thanks to all volunteers and to Joana Antunes for the collaboration and assistance.

\section{Conflict of Interests}

The authors declare that there are no financial and/or personal relationships that could be viewed as presenting a potential conflict of interests.

\section{Conclusão}

O modelo proposto parece adequado para caracterizar a microcirculação periférica in vivo.

\section{Agradecimentos}

Os autores gostariam de expressar os seus agradecimentos a todas as voluntárias e a Joana Antunes pela colaboração e assistência.

\section{Conflito de Interesses}

Os autores declaram não existir qualquer relação pessoal ou financeira que possa ser entendida como representando um potencial conflito de interesses. 


\section{References / Referências}

1. Rossi M, Carpi A. Skin microcirculation in peripheral arterial obliterative disease. Biomed Pharmacother 2004; 58: 427-431.

2. Rodrigues LM, Pinto PC, Fluhr JW. In vivo assessment of peripheral vascular function by tcpO $\square$ and skin blood flow modelling. Exp Dermatol 2012; 21(1):38-42. doi: 10.1111/j.1600-0625.2011.01398.x.

3. Abularrage CJ, Sidawy AN, Aidinian G, Singh N, Weiswasser JM, Arora S. Evaluation of the microcirculation in vascular disease. J Vasc Surg 2005; 42: 574-581.

4. Izjerman RG, de Jongh RT, Beijk MA, van Weissenbruch MM, Delemarre-van de Waa HA, Serne EH, Stehouwer CD. Individuals at increased coronary heart disease risk are characterized by an impaired microvascular function in skin. Eur J Clin Invest 2003; 33: 536-542.

5. Stewart J, Kohen A, Brouder D, Rahim F, Adler S, Garrick R, Goligorsky MS. Noninvasive interrogation of microvasculature for signs of endothelial dysfunction in patients with chronic renal failure. Am J Physiol Heart Circ Physiol 2004; 287: H2687-E2696.

6. Sokolnicki LA, Roberts SK, Wilkins BW, Basu A, Charkoudian N. Contribution of nitric oxide to cutaneous microvascular dilation in indi- viduals with type 2 diabetes mellitus. Am J Physiol Endocrinol Metab 2006; 292: E314-E318.

7. Carberry PA, Shepherd AM, Johnson JM. Resting and maximal forearm skin blood flows are reduced in hypertension. Hypertension 1992; 20: 349-355.

8. Chomard D, Habault P, Eveno D, Le Lamer $\mathrm{S}$, Ledemeney M, Haon C. Criteria predictive of limb viability at 1 year in patients with chronic severe ischemia--TcPO2 and demographic parameters. Angiology. 2000; 51(9):765-76.

9. Lo T, Sample R, Moore P, Gold P.Prediction of Wound Healing Outcome Using Skin Perfusion Pressure and Transcutaneous Oximetry: A Single-Center Experience in $100 \mathrm{~Pa}-$ tients. Wounds 2009; 21(11):310-316.
10. Poredos P, Rakovec S, Guzic-Salobir B. Determination of amputation level in ischaemic limbs using tcPO2 measurement. Vasa 2005; 34(2):108-12.

11. Takiwaki H: Measurement of transcutaneous oxygen tension, in "Hand Book of Non-Invasive Methods and the Skin" Ed. J. Serup \& G.B.E Jemec, CRC Press, Boca Raton, 1995; 185-195.

12. Rodrigues L, Ferro IZ, Galego N, Pinto P, Silva N, Rey-Salgueiros Y. Study on the application of transcutaneous $\mathrm{pO} 2$ and $\mathrm{pCO} 2$ monitoring to the in vivo functional characterization of the normal human skin, Piel span 1998; 13: 380-388.

13. Berardesca E, Leveque JL, Masson $\mathrm{Ph}$, the EEMCO Group, EEMCO guidance for the measurement of skin microcirculation: Skin Pharmacol AppI Skin Physiol 2001.

14. Hauser CJ, Klein SR, Mehringer CM, Apple P, Shoemaker WC. Superiority of transcutaneous oximetry in noninvasive vascular diagnosis in patients with diabetes Arch Surg 1984; 119: 690-694.

15. Silva H, Ferreira H, Tavares L, Bujan J, Rodrigues LM. Exploring in vivo models to characterize peripheral microcirculation - a pilot study. Biomed Biopharm Res. 2013; (10)1: 65-72.

16. Johnson WC, Grant HI, Baldwin D, Hamilton JV, Dion JM. Supplemental oxygen and dependent positioning as adjunctive measures to improve forefoot tissue oxygenation. Arch Surg 1988; 123(10):1227-1230.

17. Bongard, Krahenbuhl B: Predicting amputation in severe ischemia. J Bone Joint Surg 1988; 70B:465-467.

18. Harward TR, Volny J, Golbranson F, Bernstein EF, Fronek A: Oxygen-inhalation induced transcutaneous $\mathrm{PO} 2$ changes as predictor of amputation level. J Vasc Surg 1985; 2:220-227.

19. Moosa HH, Peitzman AB, Marakoun MS, Webster MW, Steed DL. Transcutaneous oxygen measurements in lower extremity ischemia: Effects of position, oxygen inhalation, and arterial reconstruction. Surgery 1988; 103:193-198.
20. Nakajima S, Meyer JS, Amano T, Shaw T, Okabe T, Mortel KF: Cerebral vasomotor responsiveness during $100 \%$ oxygen inhalation in cerebral ischemia. Arch Neurol 1983; 40:271-27.

21. Maroko PR, Radvany P, Braunwald E, Hale SL: Reduction of infarct size by oxygen inhalation following acute coronary occlusion. Circulation 1975; 52:360-368.

22. Langhans M, Michelson G, Groh MJ. Effect of breathing $100 \%$ oxygen on retinal and optic nerve head capillary blood flow in smokers and non-smokers. Br J Ophthalmol. 1997; 81(5):365-9

23. Bird AD, Telfer ABM: Effect of hyperbaric oxygen on limb circulation. Lancet 1965 ; 1:355-356.

24. World Medical Association. World Medical Association Declaration of Helsinki: Ethical Principles for Medical Research Involving Human Subjects. JAMA. 2013. doi: 10.1001/jama.2013.281053

25. Mouren X, Caillard P, Bensoussan J, Massonneau M, Gamand S, Stevens W. The effect of naftidrofuryl on transcutaneous oxygen tension during a treadmill test in patients with peripheral arterial occlusive disease Vasc Med 1998; 3:9. DOI: 10.1177/1358836X9800300103.

26. Hardy JC, Gray K, Whisler S, Leuenberger U. Sympathetic and blood pressure responses to voluntary apnea are augmented by hypoxemia. J Appl Physiol 1994; 77: 2360-2365.

27. Seals DR, Johnson DG, Fregosi RF. Hyperoxia lowers sympathetic activity at rest but not during exercise in humans. Am J Physiol 1991; 260: C873-C878

28. Rousseau A, Tesselaar E, Henricson J, Sjöberg F. Prostaglandins and radical oxygen species are involved in microvascular effects of hyperoxia. J Vasc Res. 2010; 47(5):44150. doi: $10.1159 / 000282667$

29. Rodrigues LM, Pinto PC, Magro JM, Fernandes M, Alves J. Exploring the Influence of skin perfusion on transepidermal water loss. Skin Res Technol 2004; 10 (4): 257-62. 